Edith Cowan University

Research Online

Research outputs 2014 to 2021

2019

Understanding visitor expectations for responsible tourism in an iconic national park: Differences between local and international visitors

Angus Morrison-Saunders

Edith Cowan University

Michael Hughes

Jenny Pope

Edith Cowan University

Anneli Douglas

Jan-Albert Wessels

Follow this and additional works at: https://ro.ecu.edu.au/ecuworkspost2013

Part of the Environmental Sciences Commons

10.1080/14724049.2019.1567740

This is an Accepted Manuscript of an article published by Taylor \& Francis in Journal of Ecotourism on 22 January 2019, Available online: https://doi.org/10.1080/14724049.2019.1567740.

Morrison-Saunders, A., Hughes, M., Pope, J., Douglas, A., \& Wessels, J. A. (2019). Understanding visitor expectations for responsible tourism in an iconic national park: differences between local and international visitors. Journal of Ecotourism,18(3) 284-294.

Published article Available here

This Journal Article is posted at Research Online.

https://ro.ecu.edu.au/ecuworkspost2013/5671 


\title{
Understanding Visitor Expectations for Responsible Tourism in an Iconic National Park: Differences between local and international visitors
}

\section{Angus Morrison-Saunders' $1,2,3$, Mike Hughes², Jenny Pope ${ }^{1,3,4}$, Anneli Douglas $^{5}$, Jan-Albert Wessels ${ }^{6}$}

1. Centre for Ecosystem Management, School of Science, Edith Cowan University, Australia

2. Environmental and Conservation Sciences, School of Veterinary and Life Sciences, Murdoch University, Western Australia

3. Research Unit for Environmental Science and Management, North West University, South Africa

4. Integral Sustainability, Australia

5. University of Pretoria, South Africa

6. University of South Africa, South Africa

\section{Correspondence}

Any correspondence should be directed to Angus Morrison-Saunders, Centre for Ecosystem Management, School of Science, Edith Cowan University, Australia (a.morrison-saunders@ecu.edu.au).

\begin{abstract}
A survey on expectations for responsible tourism was administered to 201 visitors to the iconic Kruger National Park, comprising 55\% South African nationals and 45\% international tourists. Using Likert-scale questions, respondents were invited to indicate the level of importance they attached to 38 aspects of responsible tourism. Space was also provided for open comments. Conservation of biodiversity and geological features were rated very highly by both groups while aspects related to the local community, though considered important overall, were ranked lowest overall, with international tou rists rating this category as more important than South Africans. Aspects related to traffic and access were rated to be more important by South Africans, probably because they mostly self-drive while international visitors rely more on organised game drives. Visual and aesthetic features of camps, as well as energy, water and waste management were all considered very important by all respondents, with members of both groups making further suggestions for improvement. This suggests that visitors are supportive of low environmental impact tourism in the Kruger National Park. In light of the strategic goal of South African National Parks to increase visitor numbers, it will be important that this goal is achieved without compromising sound environmental performance.
\end{abstract}

Keywords: visitor expectations, natural area management, responsible tourism 


\section{Introduction}

Understanding the expectations of visitors to natural areas is an important aspect of responsible tourism management (Moyle \& Weiler, 2017; Newsome \& Hughes, 2017; Schliephack, Moyle, \& Weiler, 2013). Like the closely-related term 'sustainable tourism', responsible tourism is usually defined in terms of minimizing negative environmental, social and economic outcomes and maximizing positive ones (Frey \& George, 2010). It has been argued, however, that the responsible tou rism discourse focuses not only on sustainable outcomes being delivered through tourism, but the behaviours and processes through which these outcomes are achieved (Mihalic, 2016). For example, Goodwin (2011, p31) argues that "responsible tourism is about everyone involved taking responsibility for making tou rism more sustainable". This means that tourists themselves have a role to play in the quest for responsible tou rism, and understanding visitor expectations for parks in this context is a first step to realise this ultimate goal for responsible tou rism.

The purpose of this Research Note is to report on a study of visitor expectations for responsible tourism for an iconic national park in South Africa. The Kruger National Park (hereafter KNP) has over time become, and still remains, the flagship conservation and tourism product offering within the National Parks system in South Africa (SANParks, undated-a) and arguably has iconic status internationally. Following the establishment of responsible tourism as a cornerstone of tourism management nationally by the South African Department of Environmental Affairs and Tourism (DEAT, 2003; Spenceley et al., 2002), South African National Parks (hereafter SANParks) made a formal commitment to responsible tou rism for its management of the national parks of South Africa in 2011 (SANParks, undated-b). Responsible tou rism is one of 'three important core pillars' of the business operations of the agency (SANParks, undated-c, p23).

Surveys of visitors at two camps within the KNP were undertaken. Responses were analysed to understand differences between expectations of international visitors regarding responsible tourism in KNP with those of South African nationals. Details of the research methodology are provided in the next section, followed by results, a brief discussion of ramifications of the research for SANParks and the wider international community interested in understanding the expectations of natural area visitors in relation to responsible tourism and the role of natural area managers in this regard.

\section{Methods}

A mixed-methods approach was adopted with the survey comprising closed and open-ended questions, along with two visitor characteristics questions. The survey questions formed part of a questionnaire examining the relationship between environmental impact assessment (EIA) and responsible tou rism development (for an ongoing research project beyond the scope of this paper). The items in the survey were initially derived from EIAs recently carried out for the two KNP camps of Tamboti and Satara, being tangible aspects of development that visitors could experience directly. South Africa's Responsible Tou rism Handbook (DEAT, 2003) was then consulted, and some further aspects of responsible tou rism not listed in the EIAs, but contained in the Handbook were added to the survey. This resulted in 38 questions. To make this list more user-friendly, similar items were grouped into six categories: visual and aesthetic environment; energy, water and air; biodiversity and 
geology; compliance, enforcement for safety and security and awareness; access and traffic; and local community (full questions with the Results in Table 1).

A five point Likert scale (ranging from 'of no importance' to 'of extreme importance) measured the importance of the survey items as perceived by KNP visitors. Following completion of these questions, respondents were then invited to elaborate on any additional aspects of importance to them in the form of open-ended comments. Two further questions were included to understand the country of origin/residence of visitors and how many times they had visited Kruger NP.

The survey questionnaire was a printed hand-out, administered by the researchers to visitors at two rest camps in the KNP. A convenience sampling approach was applied, whereby visitors were approached in the accommodation and public areas of the camps with a request to complete the survey. Data collection took place during one week in July 2017.

$\mathrm{KNP}$ is large with many rest camps offering various levels of infrastructure and amenity. The intent of this research was to obtain sufficient-completed questionnaires in the sampling period to enable statistically reliable conclusions to be drawn. The selected camps, Satara and Tamboti, are relatively close to each other in the central region of the park. Satara is one of the oldest and most established camps in KNP, featuring many permanent chalets, a large camping ground as well as shop and restaurant facilities. Tamboti is a smaller, more rustic camp providing accommodation in permanent tents, but no other amenities.

Analysis of the data was based on frequency of responses, comparing mean scores derived from the Likert scales, as well as analysis of written comments received. The mean rating scores for each of the six Likert scale question groups were calculated using the raw responses across all of the questions within each group. Pairwise comparisons between mean ratings for each question group were done using related samples T-tests. Independent samples T-tests were used to compare results between international visitors and South African nationals.

\section{Results}

A total of 201 complete survey questionnaires were obtained. The number of responses per question varied from $182(91 \%)$ to $193(96 \%)$ of the total sample, as not every person responded to every question. When comparing results for surveys obtained at Tamboti camp (43) with those of Satara (158) it was found that the expectation responses at both camps were ostensibly the same, despite the difference in nature of the two camps; hence the data is presented here for the entire sample.

Of the 201 respondents, one did not indicate their nationality. The nationality profile of the remaining 200 respondents was:

- South African $=110(55 \%)$

- International = $90(45 \%)$, comprising the Netherlands (28), UK (17), France (13), US (12), Germany (3), two each from Austria, Belgium, New Zealand and India, plus individuals from Australia, Brazil, China, United Arabs Emirates, Israel, Pakistan, Spain, Swaziland and Switzerland. 
As might be expected, South African visitors were much more likely to have previously visited KNP than international visitors, with many indicating that they had visited the park on dozens of occasions and some over 100 times.

\section{Visitor expectations for responsible tourism}

Table 1 presents the survey questions and results. The percentage of responses received at each level of the Likert scale for each aspect of responsible tourism are indicated, along with the number of respondents and the mean score.

The results show that that the aspects scoring highest in the Visual and aesthetic category were: buildings having an ecologically responsible design; buildings blending into the natural environment; privacy; and infrastructure having minimal visual impact, while scores for consideration of local culture in architecture and lighting were relatively low. All aspects of the Energy, water and air category scored highly, particularly effective waste management and quality of water available in camps. All aspects of Biodiversity and geology scored highest overall obtaining $>60 \%$ of the extreme importance rating alone. This reflects the core purpose of the $\mathrm{KNP}$ and protected areas in general, and presumably also the main interest of visitors in the first place. For the Compliance enforcement category, visitor safety and enforcement of the Park rules scored highest, but for all aspects $>75 \%$ of responses were of the great or extreme importance. For the Access and traffic category, sufficient game viewing routes scored highest and probably related to this was the lowest scoring rating for limiting the use of private transport, which may be perceived as limiting game viewing opportunities. For the Local community category, support for the employment of local people was high while opportunities being provided for tourists to interact with local people or access locally produced products were comparatively low.

Table 1 Survey questions and visitor responses

\begin{tabular}{|c|c|c|c|c|c|c|c|}
\hline $\begin{array}{l}\text { When visiting ANY of the camps in the } \\
\text { Kruger National Park, please indicate } \\
\text { how important the following aspects are } \\
\text { to you personally: }\end{array}$ & 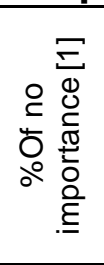 & 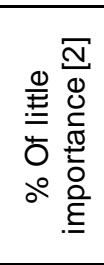 & 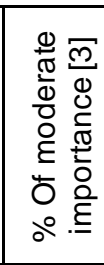 & 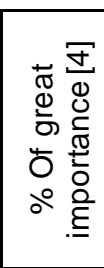 & 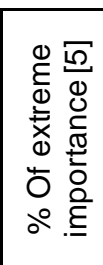 & 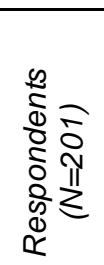 & 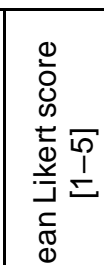 \\
\hline \multicolumn{8}{|l|}{ Visual and aesthetic } \\
\hline 1.Aesthetic appeal & 1.6 & 4.7 & 29.5 & 43.0 & 21.2 & 193 & 3.84 \\
\hline 2.Rustic setting & 3.2 & 4.7 & 18.9 & 43.7 & 29.5 & 190 & 3.95 \\
\hline $\begin{array}{l}\text { 3.Architecture of buildings blend into the natural } \\
\text { environment }\end{array}$ & 2.1 & 2.1 & 21.6 & 37.9 & 36.3 & 190 & 4.09 \\
\hline $\begin{array}{l}\text { 4.Buildings have an ecologically responsible } \\
\text { design to promote energy efficiency, water } \\
\text { conservation and climate control }\end{array}$ & 1.6 & 3.1 & 17.3 & 35.6 & 42.4 & 191 & 4.19 \\
\hline 5.Use of natural building materials & 1.0 & 5.2 & 26.6 & 38.5 & 28.6 & 192 & 3.92 \\
\hline 6.Sufficient outside lighting & 5.8 & 14.1 & 34.6 & 31.4 & 14.1 & 191 & 3.37 \\
\hline $\begin{array}{l}\text { 7.Visual impact of infrastructure be minimized } \\
\text { (lines, sub-stations, electrical fence, cell phone } \\
\text { towers etc.) }\end{array}$ & 1.6 & 3.6 & 19.2 & 36.8 & 38.9 & 193 & 4.12 \\
\hline 8.Architecture considers local culture & 6.3 & 15.1 & 24.5 & 37.5 & 16.7 & 192 & 3.49 \\
\hline 9.Privacy from other visitors and staff & 3.1 & 4.1 & 22.2 & 32.0 & 38.7 & 194 & 4.04 \\
\hline
\end{tabular}




\begin{tabular}{|c|c|c|c|c|c|c|c|}
\hline \multicolumn{6}{|l|}{ Energy, water and air } & \multirow[b]{2}{*}{190} & \multirow[b]{2}{*}{4.55} \\
\hline $\begin{array}{l}\text { 10.Effective waste management (litter, wet } \\
\text { waste, foods, general, oil spills, sewage) }\end{array}$ & 1.1 & 1.1 & 5.8 & 32.1 & 60.0 & & \\
\hline $\begin{array}{l}\text { 11.Water conservation management (dual flush } \\
\text { toilets, showers as opposed to baths, notices to } \\
\text { encourage water conservation; irrigation of } \\
\text { gardens, re-using water; maintenance of } \\
\text { leakages; storm water be collected for use in } \\
\text { cleaning or landscaping) }\end{array}$ & 2.1 & 0.5 & 6.3 & 34.9 & 56.3 & 192 & 4.49 \\
\hline 12.Using energy efficiently & 1.0 & 1.0 & 9.4 & 35.6 & 52.9 & 191 & 4.45 \\
\hline 13.Availability of electricity & 2.1 & 4.7 & 23 & 28.8 & 41.4 & 191 & 4.09 \\
\hline 14.Managing noise levels & 0 & 2.6 & 12 & 25.7 & 59.7 & 191 & 4.49 \\
\hline 15.Recycling & 0 & 3.1 & 13 & 29.7 & 54.2 & 192 & 4.41 \\
\hline $\begin{array}{l}\text { 16.Managing light pollution (from/to camp \& park } \\
\text { sources, spotlights/security lights) }\end{array}$ & 2.6 & 2.6 & 11.5 & 39.6 & 43.8 & 192 & 4.25 \\
\hline $\begin{array}{l}\text { 17.Managing objectionable odours (smell, } \\
\text { sewage, smoke etc.) }\end{array}$ & 2.1 & 1.0 & 8.9 & 26.7 & 61.3 & 191 & 4.51 \\
\hline $\begin{array}{l}\text { 18.Quality of water available in camps for human } \\
\text { consum ption }\end{array}$ & 0.5 & 5.2 & 8.9 & 19.8 & 65.6 & 192 & 4.53 \\
\hline \multicolumn{6}{|l|}{ Biodiversity and geology } & & \\
\hline $\begin{array}{l}\text { 19.Preservation of geology and scenic } \\
\text { landscape in the area }\end{array}$ & 0 & 0.5 & 5.3 & 23.9 & 70.2 & 188 & 4.69 \\
\hline $\begin{array}{l}\text { 20.Protection of biodiversity (richness, birds, } \\
\text { fauna, flora, game view experience) }\end{array}$ & 0 & 1.1 & 2.1 & 12.2 & 84.6 & 188 & 4.85 \\
\hline $\begin{array}{l}\text { 21.Landscaped areas include only local } \\
\text { indigenous species }\end{array}$ & 1.1 & 3.2 & 6.9 & 26.5 & 62.4 & 189 & 4.50 \\
\hline \multicolumn{6}{|c|}{ Compliance, enforcement for safety and security and awareness } & & \\
\hline $\begin{array}{l}\text { 22.Sustainability education/awareness } \\
\text { programmes for visitors (water conservation; } \\
\text { buying crafts that are sustainably produced and } \\
\text { locally manufactured; recycling; guidelines for } \\
\text { appropriate visitor behaviour) }\end{array}$ & 2.1 & 5.9 & 12.2 & 38.3 & 41.5 & 188 & 4.14 \\
\hline $\begin{array}{l}\text { 23. Interpretive information (explaining to visitors } \\
\text { the significance of the Park, so that they enjoy } \\
\text { their visit more and understand their heritage } \\
\text { and environment better) }\end{array}$ & 2.1 & 4.3 & 15.4 & 36.2 & 42.0 & 188 & 4.16 \\
\hline $\begin{array}{l}\text { 24.Enforcement of Park rules and regulations } \\
\text { (noise, nuisances, leaving vehicles, speeding) }\end{array}$ & 1.1 & 1.6 & 9.5 & 19 & 68.8 & 189 & 4.57 \\
\hline $\begin{array}{l}\text { 25.Adequate fencing (from animals; at swimming } \\
\text { pools etc.) }\end{array}$ & 2.7 & 3.2 & 11.4 & 31.9 & 50.8 & 185 & 4.29 \\
\hline $\begin{array}{l}\text { 26.Safety and security (from criminal elements, } \\
\text { natural disasters) }\end{array}$ & 0 & 2.6 & 7.4 & 22.8 & 67.2 & 189 & 4.59 \\
\hline \multicolumn{8}{|l|}{ Access and traffic } \\
\hline $\begin{array}{l}\text { 27.Managing congestion (at camps, on game } \\
\text { viewing roads etc.) }\end{array}$ & 1.6 & 1.6 & 15.5 & 38.0 & 43.3 & 187 & 4.24 \\
\hline 28.Sufficient game viewing routes & 0.5 & 0.5 & 6.8 & 31.6 & 60.5 & 190 & 4.55 \\
\hline 29.Quality of roads & 0.5 & 4.2 & 16.4 & 37.0 & 41.8 & 189 & 4.19 \\
\hline $\begin{array}{l}\text { 30.Access to services, facilities, products } \\
\text { (shops, swimming, entertainment). }\end{array}$ & 4.3 & 9.0 & 27.7 & 31.9 & 27.1 & 188 & 3.72 \\
\hline $\begin{array}{l}\text { 31.Limiting the use of private transport, to } \\
\text { minimise environmental impact }\end{array}$ & 10.1 & 15.3 & 25.9 & 29.6 & 19.0 & 189 & 3.35 \\
\hline 32.Sufficient parking & 4.2 & 7.4 & 23.8 & 36.0 & 28.6 & 189 & 3.81 \\
\hline 33.Cellular (mobile) phone reception & 9.7 & 15.6 & 27.4 & 23.7 & 23.7 & 186 & 3.39 \\
\hline $\begin{array}{l}\text { 34.Universal accessibility (accessibility for } \\
\text { people with disabilities) }\end{array}$ & 3.3 & 5.5 & 18.7 & 28.0 & 44.5 & 182 & 4.09 \\
\hline $\begin{array}{l}\text { 35.Opportunity to get out of your vehicle at } \\
\text { viewpoints, bridges or picnic spots }\end{array}$ & 3.7 & 6.4 & 22.5 & 9.6 & 27.8 & 189 & 3.81 \\
\hline
\end{tabular}




\begin{tabular}{|l|l|l|l|l|l|l|l|}
\hline Local community & \multicolumn{2}{|l|}{} & & \\
\hline 36.Employing the local com munity & 2.1 & 1.1 & 14.3 & 34.9 & 47.6 & 189 & 4.29 \\
\hline $\begin{array}{l}\text { 37.Opportunities are provided for tourists to } \\
\text { interact with local people }\end{array}$ & 9.1 & 15.3 & 32.3 & 24.3 & 19.0 & 189 & 3.32 \\
\hline $\begin{array}{l}\text { 38.Access to products and services produced by } \\
\text { local com munity }\end{array}$ & 7.4 & 9.0 & 28.0 & 30.7 & 24.9 & 189 & 3.60 \\
\hline
\end{tabular}

Comparing grouped mean scores for the individual questions within the six responsible tourism categories (Figure 1) shows that Biodiversity and geology was rated the highest (a), Energy, water and air, and Compliance enforcement next (b), then Access and traffic, and Visual and aesthetic (c) with Local community lowest (d). Paired comparisons $(\alpha=0.05)$ show the importance rating of Biodiversity and geology to be significantly higher than that of the Energy, water and air $(\mathrm{t}=6.862$, $\mathrm{df}=189, \mathrm{p}=0.000$ ), and hence all other question groupings. Energy water and air and Compliance and enforcement were equally rated above Access and traffic and Visual and aesthetic $(\mathrm{t}=10.67, \mathrm{df}=190, \mathrm{p}=0.000)$. Local community (d) was rated significantly lower than Visual and aesthetic $(\mathrm{t}=2.482, \mathrm{df}=191, \mathrm{p}=0.014)$.

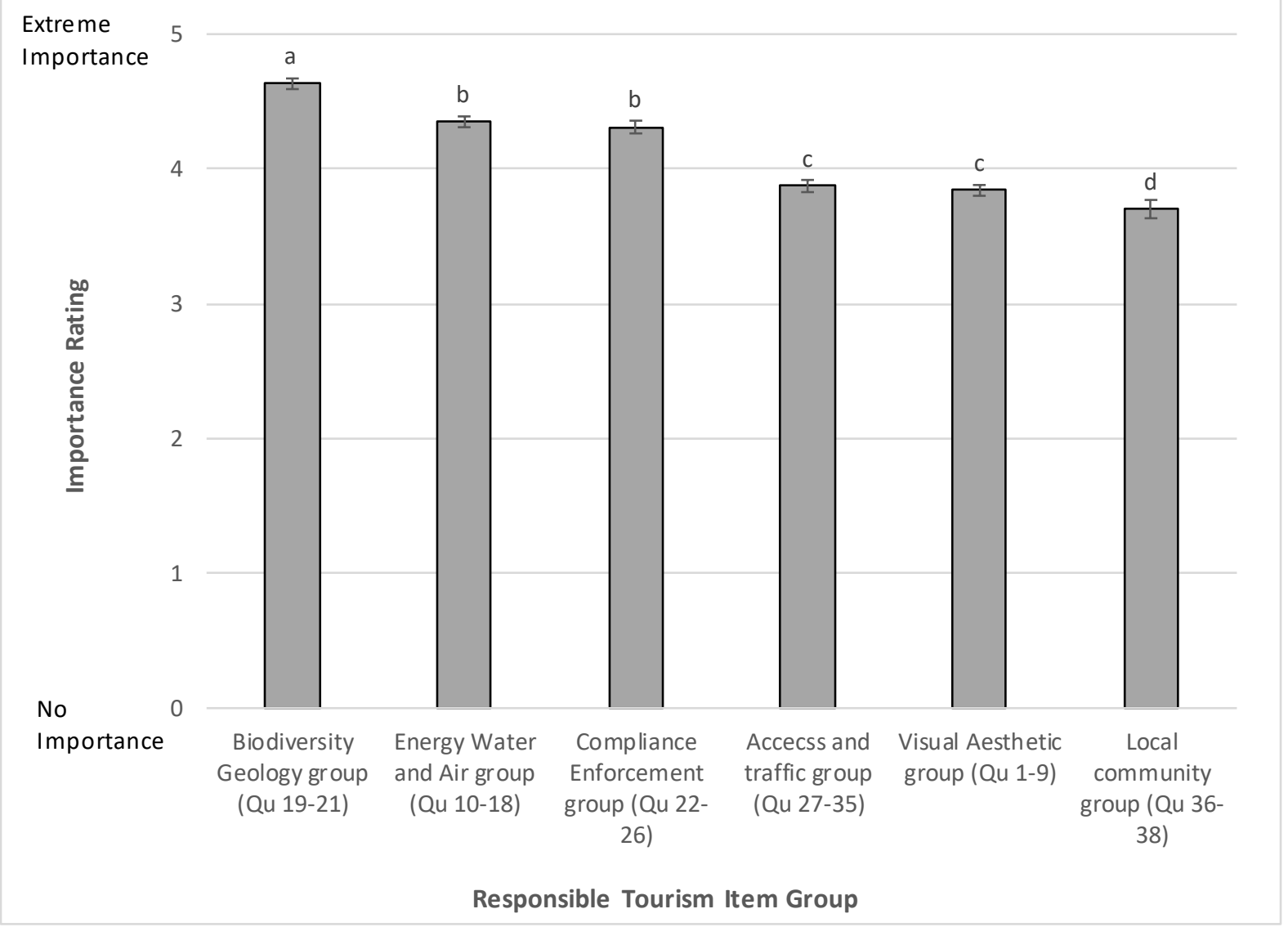

Figure 1 Grouped mean scores for responsible tourism categories (error bars = standard error of the mean, letters $(a-d)$ denote significance groupings based on related samples t-tests)

Comparison of South African nationals versus international visitors using independent samples t-tests revealed significant differences between the two visitor nationality types in relation to Energy, water and air $(\mathrm{t}=4.419, \mathrm{df}=159, \mathrm{p}=0.000)$, Compliance enforcement $(\mathrm{t}=2.308, \mathrm{df}=157, \mathrm{p}=0.022)$ and Access and traffic $(\mathrm{t}=3.857, \mathrm{df}=187, \mathrm{p}=0.000)$ (Figure 2). The latter was rated more important by 
South African visitors, probably because they typically self-drive in their own vehicles to interact with wildlife whereas many international tourists rely upon game drives operated by SANParks or other service providers.

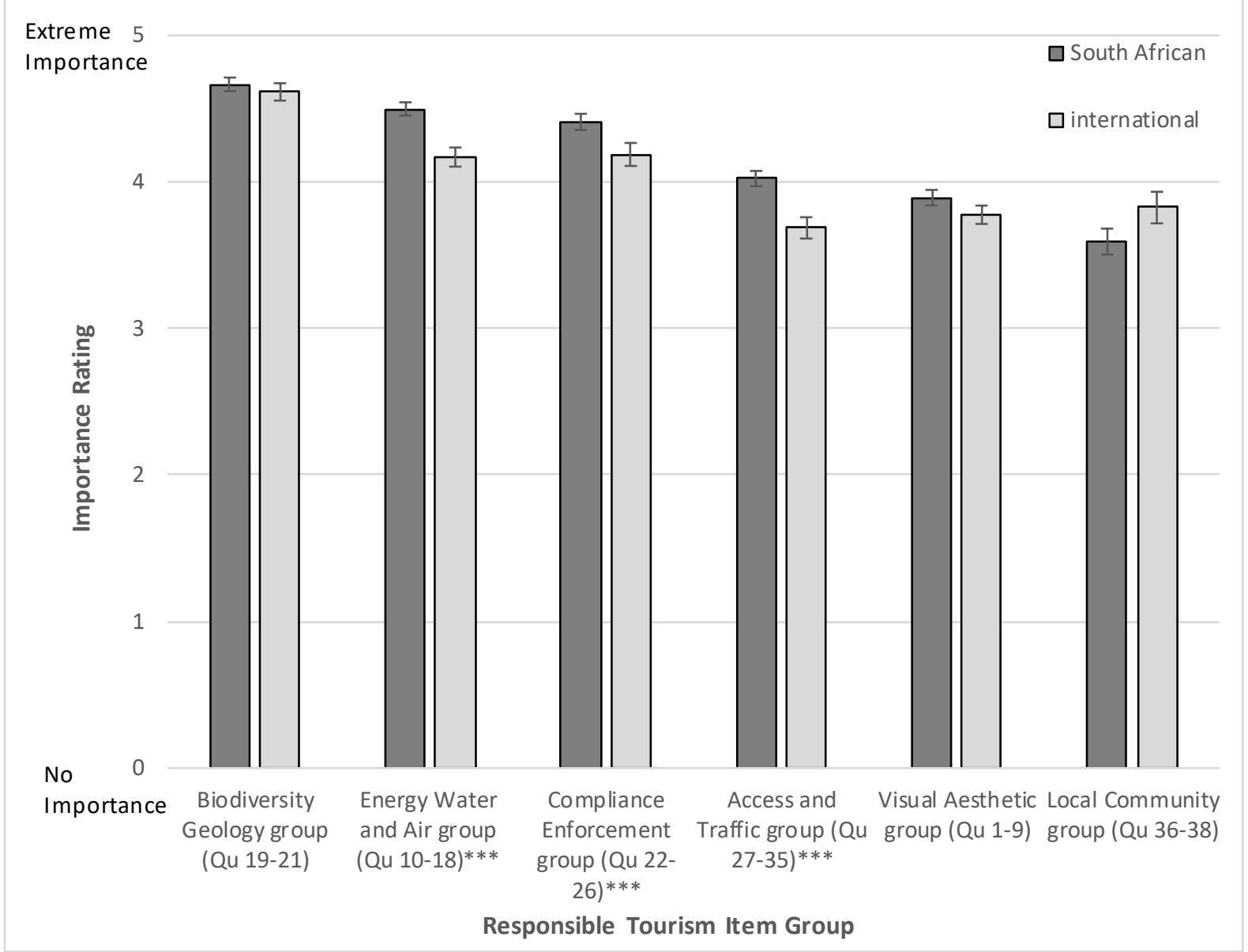

Figure 2: Comparative South African and international visitor grouped mean scores for responsible tourism categories. ${ }^{* * *}$ denotes significant difference between visitor types)

\section{Open-ended Comments}

With respect to the open-ended questions, 98 people (48\%) made comments that were retained and considered valid responses. The number of visitors commenting was approximately evenly divided with $53 \%$ South African $(n=52)$ and $47 \%$ International $(n=46)$. Consequently, any obvious differences in perspectives within the written comments could be determined based on frequency of particular responses. Although visitors were asked to respond in the context of responsible tourism, many took the opportunity to make general comments about the park and its infrastructure. Many comments were expressed as a kind of complaint or suggestion for improvement, which in some cases can be interpreted as expectations or aspirations; others praised existing aspects of park design, infrastructure or the visitor experience. Examples of comments received follow.

Suggestions for performance improvement regarding campsites and other visitor infrastructure (26) were most common; for example:

- Aesthetically pleasing but most huts require upgrades

- Improve ablutions at picnic spots 
- Keep the accommodation basic

- Renovation in some camps is necessary

- Make use of more permanent structures

South African nationals dominated these responses (73\%). This may reflect their relatively long association with the KNP, meaning that they have had the opportunity to experience different facilities in different stages of development or renovation, whereas international visitors were predominantly experiencing the park for the first time and had no point of comparison. Also, related to built infrastructure, a further 12 comments were related to expectations for the integration of buildings with the natural environment; for example:

- Buildings should blend in with the natural environment

- Maintain semi-rustic setting

- Buildings are very nice, fit into surroundings

- Maintain smallest human footprint possible

The nationality profile of people providing these comments matched that of the overall sample profile. These findings point to the importance of design of infrastructure, and on the whole, are positive in nature, praising the architectural aesthetics of the KNP camps.

Resource consumption issues also attracted numerous comments, especially water and solid waste management (25), such as:

- Must pay more if you use more electricity/water

- Housekeeping [should] adhere to water and energy saving

- Fix leaking taps

- Big camps can use grey water for gardening

- More can be done for recycling

- Make visitors more aware of how waste is managed

- Waste disposal should be split everywhere (recycle + non-recycling)

- Sorting waste is a good practice to deploy

- Practices not consistent across all camps, more recycling bins

A further 21 comments were specifically about energy efficiency or conservation measures, nearly all of which (17) specifically advocated for solar energy or more simply for renewable energy (3) to be employed. South African nationals dominated these responses (65\%), but the preference for solar energy is shared by both types of visitor. There were nine complaints about noise within the camps, especially at night time and five of these specifically referred to noise made by parks staff, and a further six comments about speeding vehicles (including those driven by staff) and a desire for better traffic control. These findings regarding resource consumption and behaviours suggest that visitors do care about the role model that SANParks provides; in this instance, all comments point to improvements in performance that could be realised. Visitors are keen for low impact environmental behaviours to be accomplished in KNP. This is an opportunity for SANParks to enhance their sustainability performance in line with visitor expectations.

A number of comments simply praised aspects of the visitor experience, especially in relation to wildlife encounters; for example:

- I appreciate that they don't cut the trees down just to give visitors a view. It's all very natural and rustic

- Great bird life \& animal noises 
but six responses related to requests for more educational resources, such as:

- Instructive pamphlets on how the park is conserving biodiversity

- More in-depth posters giving information on animals and preventing poaching

- Educate visitors to protect biodiversity through donations

These responses show the willingness of visitors to engage with the core purpose of SANParks and of the KNP for the conservation of biodiversity and reflect the high importance attached to this category in the survey.

Finally, there were small numbers of comments made about various issues such as long waiting times experienced at the gates to enter the park (4), that gravel roads should be better maintained (3), and requests for more signs and public transport options (2 each).

\section{Key Findings and Conclusions}

The survey results indicate that visitors have certain priorities regarding expectations for responsible tou rism experiences within Kruger NP. Aspects relating to biodiversity and geology protection are rated as most important by South African nationals and international visitors alike, reflecting the core focus of Kruger National Park and the biodiversity conservation mission of SANParks. While responsible tou rism principles emphasise community benefits (Leslie, 2012; Spenceley, 2008), these were relatively lower in importance to both South African and international visitors.

Recommendations for SANParks that emerge from this research are to demonstrate greater leadership in terms of:

- designing and managing infrastructure and services to enhance energy and water conservation and waste management and recycling measures to deliver more responsible outcomes; and

- ensure that staff role model other appropriate behaviours such as driving responsibly and minimising noise to set a good example to visitors.

In light of the iconic nature of the KNP and the strategic plan to increase visitor numbers to the park (SANParks, 2017: 12), such leadership could have a positive legacy that extends well beyond the park boundaries and would also save money and resources within the park itself. While the research points to ways for SANParks to enhance its performance, visitor expectations for responsible tou rism practices are largely upheld by current SANParks practices.

\section{Acknowledgements}

This research was supported by the Tourism Development \& Marketing Division of South African National Parks; access to personnel, park admittance and camp facilities is greatly appreciated.

\section{References}

DEAT - Department of Environmental Affairs and Tourism (2003) Responsible Tourism Handbook: A Guide to Good Practice for Tourism Operators, DEAT, available: https://www.eldis.org/document/A13996 [accessed 29 June 2018] 
Frey, N. and George, R. (2010) Responsible tourism management: The missing link between business owners' attitudes and behaviour in the Cape Town tourism industry. Tourism Management 31 (5), 621-628.

Goodwin, H. (2011) Taking responsibility for tourism, Goodfellow Publishers Limited Woodeaton.

Mihalic, T. (2016) Sustainable-responsible tourism discourse - Towards 'responsustable' tourism. Journal of Cleaner Production 111, 461-470.

Moyle, B. D. and Weiler, B. (2017) Revisiting the importance of visitation: Public perceptions of park benefits. Tourism and Hospitality Research 17 (1), 91-105.

Newsome, D. and Hughes, M. (2017) Jurassic World as a contemporary wildlife tourism theme park allegory. Current Issues in Tourism 20 (13), 13111319.

SANParks - South African National Parks (undated - a) Kruger National Park Attractions, available https://www.sanparks.org/parks/kruger/tourism/attractions.php [accessed 29 October 2018]

SANParks - South African National Parks (undated - b) Responsible tourism in SANParks: The journey to 2022, SANParks, available:

http://cdn.bdlive.co.za/images/pdf/SanParks tourism.pdf [accessed 29 October 2018]

SANParks - South African National Parks (undated - c) South African national parks strategic plan 2016/17-2019/20, SANParks, available: https://www.sanparks.org/assets/docs/about/5 year strategic plan 20162017 2019-2020.pdf [accessed 29 October 2018]

SANParks. 2017. South African National Parks 2016/2017 Annual Report., available https://www.sanparks.org/assets/docs/general/annual-report-2017.pdf [accessed 29 October 2018]

Schliephack, J., Moyle, B. and Weiler, B. (2013) Visitor expectations of contact with staff at a protected site. Annals of Leisure Research 16 (2), 160-174.

Spenceley, A. (2008). Introduction: responsible tourism in Southern Africa. In A. Spenceley (Ed.), Responsible Tourism: critical issues for conservation and development (pp. 2952). UK: Routledge.

Spenceley, A., Relly, P., Keyser, H., Warmeant, P., McKenzie, M., Mataboge, A., Norton, P., Mahlangu, S., and Seif, J. (2002) Responsible Tourism Manual for South Africa, Department for Environmental Affairs and Tourism, July 2002 available: http://kruger2canyons.org/031 - Responsible Tourism Manual.pdf [accessed 29 October 2018] 